John Carroll University Carroll Collected

2019

\title{
Shakespeare and Posthumanist Theory
}

Jean Feerick

John Carroll University, jfeerick@jcu.edu

Follow this and additional works at: https://collected.jcu.edu/fac_bib_2019

Part of the English Language and Literature Commons

\section{Recommended Citation}

Feerick, Jean, "Shakespeare and Posthumanist Theory" (2019). 2019 Faculty Bibliography. 57.

https://collected.jcu.edu/fac_bib_2019/57

This Book Review is brought to you for free and open access by the Faculty Bibliographies Community Homepage at Carroll Collected. It has been accepted for inclusion in 2019 Faculty Bibliography by an authorized administrator of Carroll Collected. For more information, please contact connell@jcu.edu. 


\section{Shakespeare and Posthumanist Theory By Karen Raber \\ London: Bloomsbury, 2018}

\section{Reviewer: Jean E. Feerick}

"The human is already inhuman" (145), quips Karen Raber, echo-ing the rhythms of Bruno Latour's famous title that delivered actor network theory to the world amid a call to rethink the division of culture and nature as instead an assemblage. ${ }^{1}$ In her new book for the Arden Shakespeare and Theory series, Raber takes up the dynamic and expansive field of posthumanism and the cluster of theories that subtend its philosophical position and demonstrates their relevance for and intersections with Renaissance culture, as embodied not only by Shakespeare but by a range of art prac-titioners, philosophers, rhetoricians, and scientists. Flouting the unity that posthumanist theorists tend to assign Renaissance humanism, which Raber sardonically mocks as a view of the era as a "premodern bondage machine" (4), she builds her claims out from an assertion she shares with a recent volume edited by Scott Maisano and Joseph Campana that Renaissance humanism was a set of practices that yielded less a stable notion of the human, than a compellingly self-divided way of reading that makes it a compel-ling contributor to posthumanist practice. ${ }^{2}$

Of course, this can be confusing if we construe the "post" in post-humanism as denoting temporal sequence-seeming to call up the paradox of turning the "preface" of early modernity into the "pro-logue" to our now. But Raber urges us to bracket linear models of 
thinking-which are themselves symptoms of the "exceptionalist" paradigm posthumanism assaults-and associate the prefix instead with an inclination to scatter the category of the human, construing it as an ontology that is ongoing, mediated, extended, unstable, and always in progress as it seeks to define itself in opposition to a moving assemblage of "others." In exposing and exploring the breadth of human embeddedness in and attachment to various objects, environments, and creatures in the work of Shakespeare and others, Raber reads Renaissance materials as providing important access to a moment that was open to the paradoxes of human identity, one not yet seeking cover in Cartesian dualism and the myth of a transcendent reasoning faculty it helped to fuel. As she argues, "Renaissance humanism did not (always) seek to extract humanity from the mesh of beings in the world" (21). Rather, in her account, it understood and at times even celebrated an awareness that the human has never been fully human, although it is also true that Enlightenment humanism has sometimes obscured our access to this point.

Raber's book is lively, informative, theoretical, and expressive of sharp close readings. I see it as a treasure trove for critics and students alike. One of the things I found particularly exciting about her accounl of posthumanism is how she treats this capacious theory as a kind of switchboard that opens pathways to and from a range of philosophical and political projects, including ecocriticism, new materialism, animal studies, phenomenology, extended and distributed cognition, embodied identity, disability theory, and cyborg studies, among others. Raber has distilled the wisdom of an impressive range of theorists-from Hayles and Braidotti to Derrida, Delueze, Haraway, Bennett, and Latourpresenting each in digestible chunks for her readers, while also placing them in relation to one another. This is one of her particular skills-identifying and clarifying the salient points of complex theoretical arguments and then putting them in dialogue with one another. 'loward this end, she animates Haraway's critique of Deleuze and her embrace of Latour. And she narrates Derrida and Agamben as they respond to Descartes. She is on very sound footing philosophically, although she occasionally apologizes for condensing whole traditions into a few paragraphs. Since that is precisely what the volume calls for, she meets the challenge with aplomb. She also tracks the development and significance of whole fields in Renaissance studies such as humoralism, phenomenology 
and animal studies, showing how they contribute to and echo the foundational claims of posthumanism. Reading her book as I was designing a graduate course on Ecocriticism and Renaissance Literature, I came to see it as a terrific resource for students who might need a crisp account of Latour, Bogost, or Agamben to allow them to join the critical conversation.

Her chapters, too, had a design that emblematized the feel of networks and assemblages in action, as opposed to taut, linear arguments set up to overturn earlier readings or critical models. Raber has opted to creatively cluster her chapters around a theoretical approach, such as animal studies or cyborg theory; a defining trope, such as the face as interchange between body and mind or the centaur as emblem of the human/animal dyad; and a set of texts, including Shakespeare's plays but also a range of other cultural artifacts. At times, she dives deeply into readings of the plays, as she does in her first chapter in grappling with King Lear's "queer cosmos," a phrase she borrows from Laurie Shannon. ${ }^{3}$ Elsewhere, her method shifts, as when she turns to well-charted areas such as animal studies or theories of embodiment, which have been deeply mined by recent criticism and have yielded multiple rich, capacious studies in article and monograph form. In chapter 3, for instance, she spends less time in providing a new reading of a play than in threading connections between the work of posthumanist theorists like N. Katherine Hayles and Stacy Alaimo and that of early modernists like Gail Paster, Bruce Smith, and Holly Dugan in areas like humoral embodiment, phenomenology, or disability theory. As she demonstrates in accounting for scholarship that spans roughly two decades, early modern critics have been uncovering in Renaissance texts a conception of the human that is dispersed, extended, and embedded, one that bears uncanny resemblance to posthumanism and supports her thesis that returning to this era can creatively inflect and enrichen the posthumanist project, as well as revitalize study of Shakespeare by posing new questions and making us alert to new archives and angles.

In the second half of the book, she explores the animal and cyborg dimensions of human identity for Renaissance writers. Chapter 4 charts the ubiquity and conceptual centrality of animals-or creaturely life-in Shakespeare's plays, concluding with a discussion of Tilus Andronicus. Notable in this chapter is her discussion of the name that Shakespeare's character Chiron shares with the eldest centaur of Greek mythology, etymologically 
linked to the word for "hand," which identifies and explains the figure's longstanding association with skill in the use of tools, instruments, and other objects to denote his human-like mastery over nature. Compellingly, Shakespeare's character inverts all such associations when he unleashes bestial violence on Rome, beginning with his ravagement of Lavinia, thereby dismantling the category of the human and exposing violence as the foundation upon which civilization rests. Raber's last full chapter tacks toward the inhuman, exploring imaginative engagements with the shaping powers of technology in a Renaissance era defined by a "seismic shift in the speed and nature of knowledge transmission" (130). Discussions of Giovanni Bracelli’s and Albrecht Dürer's geometric renderings of the human body as an assemblage of object-like parts-a kind of robot-dovetails into a discussion of the cyborgian armored warrior of Shakespeare's history plays, which stage a relentless twinning of men and metal on the battlefield. In donning armor, wielding weapons, and commanding men, Shakespeare's warriors operate as "extended, fortified beings... made up of other human and non-human stuff" (152-53). They morph, that is, into iron men.

And yet, it was in the sustained close reading that comprises her first chapter on Lear that I found Raber to be at her best in enacting the value that posthumanist theories and reading practices have for canonical plays. Itself a play that has been at the center of important articles from the perspective of animal studies (Shannon) and eco-critical approaches (Egan and Mentz), Lear here is yet made to articulate a new kind of posthumanist perspective, as Raber weighs the shifting representations of the natural world that express the characters' disparate moral and political sensibilities, from the selfinterested cunning of an Edmund to the ethical certainty of an Edgar or Kent. Positioning herself against theories of orderly and hierarchical life made famous by Tillyard and aligning her reading instead with theories of tumult and disharmony implicitly advanced long ago by Arthur Lovejoy and, more recently, by Steve Mentz, Raber argues that the play stages the strategies of control that humans use to counter the overwhelming experience of being confronted by "hyperobjects," the term Timothy Morton has assigned to material forces so large and powerful that they confound human conceptualization. ${ }^{4}$ In the case of Lear, the dance between assertions of an ordered and providential universe and the abiding sense of nature as an unwieldy, entropic force that haunts 
the play serves as a tacit acknowledgment by the dramatist that powerful cosmic activities leave us bewildered, grasping at organizing patterns to hold chaos at bay. For Raber, the play reduces its characters to the "humility of unknowing" (52), a posture that she sees as powerfully emblematized by the stumbling, foolish figure of Gloucester, who smells and feels his way to Dover, a mere groveling creature unable to distinguish life from death. Notably, Raber returns to the figure of Gloucester in her brief final chapter, identifying the unknowing man-animal as a fitting emblem of posthumanism, one who disperses the comforting fictions of "life, love, and family" (161) that gather around the "plays' charismatic megafauna like Cordelia, Edgar, Kent, or Lear himself” (161).

In threading the theory of hyperobjects into this play, Raber echoes a question once raised by A. C. Bradley who asked, in effect, why must Gloucester head all the way to Dover to die? Raber follows this lead in speculating that part of Dover's appeal lies in its recent devastation at the hands of a massive earthquake in 1580 that tumbled houses and spawned tsunamis, seeming to strike at the very symbols of human civilization. Shakespeare's characters evoke this place repeatedly in the play, Raber proposes, as a sort of return to and evocation of a moment of collective trauma. I confess, I was intrigued by these details, not knowing of these associations or events. But I also found the shift to topicality as a guiding heuristic at a key moment in the chapter to sit in uneasy relation with Raber's dexterous use of more agile theoretical models elsewhere. Topicality has, it should be said, become a preferred analytical mode for some, if not all eco-critics, who seem to gravitate toward and privilege empirical facts-pollution, deforestation, fossil fuels-to bridge early modernity to the "now" of ecological devastation. But Raber understands that even as eco-criticism and posthumanism overlap, they are not contiguous and may even occasionally be in tension. I see such a tension in her turn to the topical as a kind of key that grants privileged access to the text, precisely because it seems to underscore a way of thinking that privileges "turning points or historical pivots" (159) and thereby betrays a bid for epistemological mastery that is at odds with posthumanism. I applaud instead the skeptical posture Raber elsewhere applies to "stabilizing" readings that concede a privileged view to the modern critic, preferring lo guard against totalizing critical moves in order to underscore the presence of a range of actants historically, whether ontologically or epistemologically. Her final brief 
chapter, in fact, is an eloquent call for such a practice, which she describes as a "slow, disabled, but environmentally aware posthumanism," which "arises out of millions of cellular pulses across the strands of culture, the academy and individuals over a longer temporal arc" $(160-61)$. It is a posthumanism not limited to Shakespeareans, nor to practitioners of the humanities, nor even to humankind. She may be appealing to a scholarly version of the Parliament of Things famously evoked by Latour as a working model for a more equitable political practice in which the voice and interests of all actants-human and nonhuman-affected by a given policy gain representation in the political process. Raber's book helpfully points us in a similar direction for our scholarly practice, urging us to be on the lookout for those moments when "human subjectivity is king and the earth [or the past] merely an object to know" (49). She concludes by puzzling over the potentially crippling paradox for the kind of posthumanism she advocates, which is a deeply ethical and political practice as well as a theoretical model. If there is no human subject to stand as the "origin of decision-making" and the engine of ethical practice, how do posthumanists purport "to transform and improve human beings-if not the beings themselves, then their effects on their fellow creatures and on the places we have to live" (25), the goal that inspires much of this work? In response, Raber fittingly provides another question: "Might we need both a strategic subjectivity and a strategic exceptionalism to put ethics into practice as politics or law?" (162). Open-ended, qualified, dialogical, and performative-this and the other questions with which she concludes her study invite us to add our voices and our studies to the network of "millions of cellular pulses" (160) which she identifies with the slow work of undoing human exceptionalism.

\section{Notes}

1. Bruno Latour, We Have Never Been Modern, trans. Catherine Porter (Cambridge, MA: Harvard University Press, 1993).

2. See the Introduction to Joseph Campana and Scott Maisano, eds., Renaissance Posthumanism (New York: Fordham University Press, 2016).

3. Laurie Shannon, “Lear's Queer Cosmos" in Madhavi Menon, ed, Shakesqueer: A Queer Companion to the Complete Works of Shakespeare (Durham. NC: Duke University Press, 2011): 171-78.

4. Timothy Morton, Hyperohjects: Philosophy and Ecology after the End of the World (Minneapolis: University of Minnesota Press, 2013). 